\title{
Impact of Chagas Disease on Human Evolution: The Challenges Continue
}

\author{
Elaine Cristina Navarro ${ }^{1,2}$, Paulo Câmara Marques Pereira ${ }^{1}$ \\ ${ }^{1}$ Tropical Diseases Department, Botucatu School of Medicine, São Paulo State University-UNESP, \\ Botucatu, Brazil \\ ${ }^{2}$ School Eduvale de Avaré, Avaré, Brazil \\ Email: navarro@fc.unesp.br
}

Received June $27^{\text {th }}$, 2013; revised July $29^{\text {th }}$, 2013; accepted August $27^{\text {th }}$, 2013

\begin{abstract}
Copyright (c) 2013 Elaine Cristina Navarro, Paulo Câmara Marques Pereira. This is an open access article distributed under the Creative Commons Attribution License, which permits unrestricted use, distribution, and reproduction in any medium, provided the original work is properly cited.
\end{abstract}

\begin{abstract}
Chagas disease affects 8 to 10 million people worldwide and, although most of them live in Latin America, there has been an increase in cases occurring in countries of Europe and North America although most of them live in Latin America. This study aims to describe the epidemiological situation in the present as well as government and research centers actions, particularly the study group of Chagas disease of the School of Medicine of Botucatu (FMB/UNESP)/Brazil.
\end{abstract}

Keywords: Congenital Transmission; Epidemiology; Vector Control; Chagas Disease

\section{Introduction}

Chagas disease (CD), also known as American trypanosomeasis, was discovered over 100 years ago (1909) and still affects thousands of people in the world, particularly in America.

$\mathrm{CD}$ is considered by some authors as the most neglected diseases and it happens for many reasons, but two of them stand out: 1) most of the carriers present the indeterminate way (no symptoms) and spend most of their lives without knowing their condition and without medical monitoring; and 2) these people are socially and financially disadvantaged and, thus, there's no commercial interest in researching and producing new medications.

The goal of this study is to describe the epidemiological situation of this disease in Brazil nowadays, which affects about 10 million people throughout the world, in what concerns to the measures taken by public authorities and in researches made in the country, particularly at the Medicine College of Botucatu (FMB/Unesp)/Brazil.

\section{The Natural History of the Parasite}

The etiologic agent of the disease is Trypanosoma cruzi, a flagellate protozoan of the order Kinetoplastida, which is characterized by the presence of a Circular Extranuclear DNA that corresponds to mitochondrial DNA (Araújo et al., 2009; Rey, 2011).

It was initially believed that trypanosomides were monogenetic parasites of insects which didn't suck blood, but during the evolution process these ones identified some animals as a new food source and started to suck blood. Trypanosomes suffered morphological and functional changes to survive, as the development of the undulating membrane and the scourge allowed the circulation in the blood of the host (Coura \& Borges-
Pereira, 2011).

According to Coura (2007), the most accepted hypothesis about the natural history of the disease can be divided in four phases: 1) enzooty-infection among wild animals, and it persists until now in some locations as the Amazon; 2) anthropozoonosis-transmission among humans and animals in ecotopes; 3) zoonosis-among animals and humans with domesticcated vectors; 4) zooanthroponosis-transmission among old endemic areas.

In a study made by Aufderheide et al. (2004) with 283 mummies located among the coastal area of South America, Atacama Desert in Southern Peru and the Northern Chile found the existence of 9000-year-old mummies. In this study it was also proved that $40.6 \%$ were seropositive for Trypanosoma cruzi. At the "Abrigo do Malhador" archeological site, in Minas Gerais, Brazil, some molecular tests were made in mummies of adult $560 \pm 40$ year-old men (Carbon-14 dating) which presented megacolon and Trypanosoma cruzi I in a period that precedes the European colonization (Fernandes et al., 2008).

Until the 1980's, the strains of T. cruzi were subdivided in three groups (zymodemes): I, II and Z3. I and Z3 (III) were considered wild and II was considered domestic. With the advances in molecular biology techniques, nowadays we can say that the parasite presents a big genetic diversity and, thus, can be classified in six groups determined DTU (Discrete Typing Unit) that have immunological and molecular markers in common. The strains I (wild) and II (domestic) are pure and from III to IV are hybrids (Rassi Jr., Rassi, \& Marin-Neto, 2010; Zingales, 2011).

In the last 300 years, the human invasion in wild environment, deforestation and cattle breeding have favored the settlement of domestic and peridomestic cycle (COURA, 2007). The studies mentioned above corroborate the theories that the $T$. cruzi evolved along with the men. 


\section{The Discovery of the Disease}

In 1907, Dr. Carlos Ribeiro Justiniano Chagas was designated by Dr. Oswaldo Gonçalves Cruz, by that time president of the Oswaldo Cruz Institute (Rio), to control the Malaria endemic among people who worked in the construction of the “Estrada de Ferro Central do Brasil” Railway in Minas Gerais (MG). In this occasion, Carlos Chagas settled in the city of Lassance, where he utilized a wagon train as his house, office and laboratory (Goldbaum \& Barreto, 2008; Chagas, 2008).

In 1908, in one of his researches, he identified a species of trypanosome in a Callithrix penicillata, which received the denomination of Trypanosomominasese. In the same year, advised by the head of the commission of engineers of the railway, Cornélio Mota, he started intestinal analysis in triatomines (Panstrongylus megistus) that infested the workers' housing. In this insect he identified a new species of trypanosome, in which he observed the amastigote form and sent some examples to Oswald Cruz in Rio to confirm his discovery. When it was confirmed, Carlos Chagas honored Oswaldo Cruz, naming the new species Trypanosoma cruzi (Coura, 1997).

Carlos Chagas continued his studies about the new species in Lassance and, in 1909, identified the protozoan in a 2-year-old child, Berenice, who presented the acute form of the disease (Moncayo, 2009).

The discoveries of Carlos Chagas made him the only researcher to identify the etiological agent, the mechanisms of transmission and the clinical characteristics. The repercussion of this triad made the National Academy of Medicine send five members to the city of Lassance to check "in loco" this discovery and, in this occasion, Miguel Couto, member of the commission, purposed to name the etymology "Chagas disease" (Coura, 1997).

The discovery of this pathology had great world repercussion and, in 1912, Carlos Chagas had his act recognized by the Institute for Tropical Medicine of Hamburg (Germany), which granted him the Schaudinn prize for the best work in protozoology, a prize which, by that time, had been given to only other three researchers. After the international acknowledgement of this pathology importance, the federal government released special funds for the construction of a hospital in Lassance, making the clinical studies of the disease possible, as well as the other biological aspects (Schapachnik et al., 2009; Kropf, 2013).

Carlos Chagas received many other titles and honors, among these the Artium Magistrum, Honorary Degree by the Harvard University (1921); Doctor Honorary Degree by the University of Paris (1926); University of Lima (1929) and the Free University of Brussels (1934). Despite his unique achievement in the history of the World Medicine and being indicated twice to the Nobel Prize of Medicine $(1911,1920)$, the Brazilian doctor never received that title.

Other researchers continued the studies about American trypanosomiasis in various strands: Brumpt (xenodiagnosis); Guerreira \& Machado (Fixation of Complement Reaction); Viana and Margarino Torres (acute form); EvandroChagas (electrocardiographic diagnosis); Freitas (transmission through blood donation); Nussenzweig (Trypanosoma action of gentian violet); Rassi, Andrade and Prata (Chagas heart disease); Rezende (digestive form); Coura (treatment); Strout (concentration of hemoflagellates in the blood) and others (Coura, 1997).

\section{Mechanisms of Transmission}

There are many ways to transmit the disease: through vector, transfusion, congenital, oral, transplant of solid organs or bone marrow, anal glands of marsupials, laboratory accidents and through sex, but the first four are the most important ones (Dia, Neto, \& Luna, 2011).

Chagas Disease is endemic in Latin American countries, with a strong focus in rural zones where the population has low purchasing power and the houses provide favorable conditions for the triatomine (vector) to install and reproduce. The Brazilian government started campaigns for vector control in the 1950's in some areas of the country and in the 1980's there were control programs in all the national territory (Petherick, 2010). Brazil was certificated, in 2006, by the Pan American Health Organization (PAHO), as an area free from the vector transmission of triatomine Triatoma infestans, main vector of the country, which doesn't mean the compete interruption of the vector transmission, but an effective control (Fitarelli \& Horn, 2009).

Despite the control of Triatoma infestans, there's a possibility of an ecological succession and, thus, other species of triatomines could transmit Chagas disease. According to that, the study group of the Medicine College of Botucatu (SP) has been developing a great multicenter epidemiological project in a historically endemic area for an analysis in loco with the intention of checking pets which could be hosts for the parasite. In the last decade, Lucheis et al. (2005) evaluated 50 dogs in different cities in the region of Botucatu through artificial xenodiagnosis, blood culture and PCR and find that 50\% presented fragment of the parasite $\mathrm{kDNA}$.

After the interruption of the vector transmission, the blood transfusions became the main concern of Brazilian authorities regarding to the disease control and, thus, a strict legislation was elaborated, which prohibited the remuneration to the donors and implanted the mandatory serological screening in all Blood Banks (Dias, 2006).

Another important measurement determined by Brazilian authorities was the compulsoriness of serological test of high sensibility and, thus, even if the parasite load is too low, it will be detected. The main inconvenient of these tests would be the occurrence of cross reaction (false positive), but the kits used have been presenting a growing efficiency. The authors of this study performed, at the Blood center of Botucatu (FMB/ UNESP), a lifting of non-negative serological reactions for Chagas Disease (positive and inconclusive) between the years 2003 and 2010 and the average of inconclusive negative reactions was below 35\% (Navarro et al., 2013a). Another study made in the same work evaluated the inconclusive serological reactions through different methods (ELISA, HAI, IFI and immunoblotting TESA-cruzi) and concluded that TESA-cruzi is the best method to confirm the positive serology of individuals that present over two inconclusive reactions (Picka et al., 2007).

Another kind of contamination obtained more attention in the last decade, the oral transmission. Until 2004, there were few reports in literature about foods and drinks potentially dangerous to health related to Chagas Disease, but after the outbreak in the state of Santa Catarina in 2005, new outbreaks were registered, mainly in the northern region of the country, where people often consume Açai in natura. Only in the state of Pará the oral transmission was responsible for 178 cases of Chagas disease in the acute form, in 2006. Brazilian authorities instituted standards of good ways of production and compulsoriness 
of pasteurization of drinks and foods related to the oral transmission of Chagas Disease (Nobrega et al., 2009).

In the last two decades, the congenital transmission has been receiving a special attention in several non-endemic countries for Chagas Disease. Due to the migration of women from Latin America to European countries and to North America, some countries established the compulsoriness of serology to Chagas Disease in pregnant women from Latin American countries. The screening is not standardized in the different countries and, in Brazil, there are few studies of Chagas Disease in pregnant women and the confirmatory serology is not a part of the prenatal routine, not even in historically endemic areas.

In a study which was made in seven hospitals of Madrid, Spain, with 3839 pregnant Latin women, we could see the prevalence of $3.96 \%$ of serum reagent women for Chagas Disease and the rate of congenital transmission was $2.6 \%$, showing the impact of this kind of transmission of the disease (FloresChavez et al., 2011). Romero et al. (2011) found that the prevalence of women in fertile age in the rural population of Bolivia who host $T$. cruzi is bigger than $60 \%$ and the rate of congenital transmission reaches $4 \%$.

According to Bern \& Montgomery (2009), the control of congenital transmission represents the main kind of prevention of Chagas Disease in countries where there are no vector insects.

For Rissio et al. (2010), the control of congenital transmission should be settled as a priority of public health, because it has been put in evidence as one of the main kinds of transmission that we have these days and it could transmit the disease to all the world.

Some Latin country's already instituted prenatal screening for CD, like Paraguay, Uruguay, some places in Argentina. In Brazil, the screening of pregnant is not a part of the national program, but exist the entity (APAE) Association of Parents of Exceptional Children, that makes this process in Mato Grosso do Sul state and Goiás (Dias et al., 2011).

In Brazil, the control of the congenital transmissions is still initial, but some research groups are already organizing themselves in several places of the country, particularly the present authors of the study of the Medicine College of Botucatu.

\section{Clinical Forms}

The acute form of the CD is usually asymptomatic, but when symptomatic it can present prolonged fever, malaise, increasing liver and/or spleen, swollen lymph nodes, localized or generalized subcutaneous edema, signals of the input port of the parasite (Romanã signal or inoculation of Chagoma) and, rarely, cardiac alterations (Rassi Jr., Rassi, \& Marin-Neto, 2010).

The chronic form of the disease can follow distinct courses: around $60 \%$ of the parasitized individuals present the undetermined form (asymptomatic); 20\% to 40\% develop the cardiac form and or digestive (Sathler-Avelar et al., 2009).

In researches made by Geraix et al. (2007) at the Hospital of Clinics in Botucatu was observed that more than $70 \%$ of the patients presented the undetermined form, followed by the digestive, cardiac and mixed.

As Lescure et al. (2010), the cardiac form of the disease leads to abnormality in the conduction system and the more common manifestations are the palpitations, arrhythmias and several degrees of cardiac blockages. The digestive form is responsible for the development of the syndrome of "enlarge- ment” of the esophagus (dysphasia, chest pain and regurgitation) and colon (chronic constipation, abdominal pain and obstruction).

There is little information about the transition in the chronic form, but some studies indicate that the adipose tissue in an endocrine organ is capable of producing several pro and antiinflammatory cytokines, acting both as the control of parasitemia as in the tissue damage (Nagajyothi et al., 2012).

The increase of the body fat is particularly important to the carriers of the undetermined form of CD, because several studies indicate that the adipose tissue also works as a reservoir for the Trypanosome cruzi, being the responsible for the increase of the parasite load, increase of the macrophage, and the maintenance of a low degree of persistent chronic inflammation like the ones founded in morbidly obsess. Some authors also report that it's an imbalance in the process of regulation between the pro and anti-inflammatory cytokines, increasing the chances of tissue damage for the person (Combs et al., 2005; Nagajyothi et al., 2009; Ferreira et al., 2011; Tanowitz et al., 2011; Nagajyothi et al., 2012).

At the Ambulatory of Nutrition in Tropical Diseases at Hospital of Clinics of Medicine College in Botucatu were evaluated 74 individuals carriers of the intermediate form of $\mathrm{CD}$ and it was observed that $90 \%$ presented increasing of the body fat, particularly at the abdominal region, indicating higher risk of the development of the cardiovascular disease (Navarro et al., 2013b).

\section{Epidemiological Situation}

According to the Pan American Health Organization (PAHO) $\mathrm{CD}$ is present in 21 countries of the Americas and affects 8 to 10 million people in the world. The annual incidence is 41 thousand of new cases and the population exposed to danger areas reaches 100 million. In the year of 2008, 12 thousand people died, as victims of CD (Soares, 2009; PAHO, 2012).

According to Petherick (2010) in Brazil there are, at least, 3 million infected and, the country has the most part of the people with the chronic CD present and the undetermined form of the disease (with no symptoms), there is a possibility of this number being even bigger.

The control of the vector transmission of CD began in 1943 with the creation of the "Center of Studies and Prophylaxis of the Chagas Disease" of the Oswaldo Cruz Foundation. The main action of this program was to control the vectors known as "barbers" by applying insecticide, in particular at gammexane, P 530. In 1970 the control of the disease became responsibility of the Supervision of Public Health Campaigns (SUCAM) and, in 1991 the National Foundation of Health (FUNASA) took the control of all the endemic diseases. At the same time, the countries of South America (Argentina, Brazil, Chile, Uruguay, Paraguay, Bolivia and Peru) that concentrated two-thirds of the carriers of the disease in the Americas began a program of international cooperation, the "Initiative of the Southern Cone", which aimed the control the vector transmission and transfusion. The impact of this initiative was crucial for the control of vector transmission of the disease, and, in 1997 Uruguay received the certification of free area of vector transmission, followed by Chile (1999) and Brazil (2006). Another goal achieved was the mandatory of the screening serological in blood banks at Argentina (100\% of the public banks and $80 \%$ of the private), Brazil, Chile and Uruguay (100\%). Paraguay, 
Bolivia and Peru still fight against the disease, but they couldn't achieve the programmed target (Moncayo \& Silveira, 2009; Silveira \& Junior, 2011).

Several studies were performed by the Brazilian researches to ascertain the effectiveness of the vector control performed by the public authorities. Carvalho et al. (2011) performed epidemiological studies between 1976 and 1980 with more than 31 thousand people in the micro regions of Campos de Itapetininga and at Mantiquera Paulista Western Slope which was observed that the most part of the carriers of the parasite were over 40 years old, but $45 \%$ of the carriers were younger than 20 years old and more than $15 \%$ of the women were in a fertile age, signaling the possibility of the congenital transmission.

Another study about the seroprevalence of the CD were performed by Ostermayer et al. (2011) with a representative sample of the population aged up to 5 years old (104.945 children) of all the Brazilian rural area (except Rio de Janeiro) found just 32 positives $(0.03 \%)$ and from these, $20(0.02 \%)$ possibly had the congenital transmission (mother with a positive serology) and $11(0.01 \%)$ indicated possible vector transmission (9 children from the northeast area, 1 from the Amazonia and 1 from Paraná). At the same study, we observed that $60 \%$ of the children that acquired the parasite from the mother lived in Rio Grande do Sul.

The transmissions control measures of the disease are also monitored through epidemiological surveys at blood banks. In study performed by Navarro et al. (2013a) at the Hemocenter of Botucatu, town inside of the State of São Paulo, the prevalence of no negative reactions (positives and inconclusive) was of $0.5 \%$, which is the biggest national average $(0.2 \%)$-(MoraesSouza \& Ferreira-Silva, 2011).

In the semi arid zone of the state of Rio Grande do Norte (Brazil) were evaluated 1950 blood samples at the macro west region and more than 390 in Caicó and was observed that the infection persists high at the macro west region, but it's declining in Caicó (Brito et al., 2012).

Some European countries are also feeling the impact of the $\mathrm{CD}$. Spain, country that receives the higher contingent of Latin immigrants, especially from Bolivia (162.095) and that signaled to the local authorities the need of serological screening in Latin people and pregnant Latin women (Navarro et al., 2012).

In a study performed by Flores-Chaves et al. (2011) in Madrid, Spain, were made serological tests in 3839 pregnant women in seven different hospitals, in which $3.96 \%$ presented positive serology for $\mathrm{CD}$. In the same study were evaluated the newborns of these women and the rate of transmission was $2.6 \%$. When the evaluation was performed according to the origin country was identified that $95.4 \%$ were Bolivian women.

Whereas the vector control in several countries of Latin America and in Europe, there are no records that this kind of transmission should be considered the impact of congenial transmission in the maintenance of the disease in several countries and establish protocols of strict control, preventing the maintenance of new disease reservoir.

\section{Future Prospects}

The authorities of public health in Latin America made many efforts in order to control the several forms of transmission of Chagas disease (CD), but there are still many goals to be accomplished for the effectiveness in the elimination of parasites in humans.
Among these goals there are two crucial methods for the control of the disease: permanent surveillance in historically endemic areas so far about the invasion of domestic and per domestic areas of secondary species that can transmit the parasite and the control of congenital transmission.

The Initiative of the Southern Cone favored the effective control of the disease in some countries, but there are still goals that weren't achieved, as the serological screening in every blood donation and the control of the congenital transmission, thus, there is the necessity of a meeting of efforts among Latin countries with the goal of eliminate the circulation of these parasite between human hosts and their pets, which are also reservoir for the disease.

The preventive diagnoses of the congenital transmission have big impact on the public health, the available medications today have great efficiency in the acute form of the disease, preventing the cycle of the parasite continues.

Another important step related to this pathology is the development of new drugs. Currently there are two drugs marketed that act effectively in the acute phase (Benzonidazol \& Nifurtimox), but the same effect is not proportionate in the chronic stage. Moreover, the collateral damages of these drugs are intense and responsible for the abandonment of many patients.

Until the year 2011, the medicines used in the treatment of the $\mathrm{CD}$ were produced by the Pharmaceutical Laboratory of the State of Pernambuco (LAFEPE/Brazil) supported by DNDi (Drugs for Neglected Diseases Initiative) that, despite many difficulties, produced medicines for the treatment of patients around the world, but in 2012 the joint efforts of the Argentine Health Ministry and the "Fundación Mundo Sano" allowed the production of Benzonidazol in more than one laboratory. The production is still little and not available to exportation, however.

One of the biggest conquests in the treatment of $\mathrm{CD}$ was the development of dispersible tablets used in the pediatric treatment of the $\mathrm{CD}$ as before, parents needed to fractionate the medicine in twelve parts, favoring failures in the treatment due to incorrect doses. The pediatric treatment is produced only in Brazil.

Brazil is also the pioneer in the study of new drugs. Researches of the Medicine College of Riberão Preto (FMRP/ Brazil) are patenting a new drug used in combating CD. The researchers associated Benzonidazol to nitric oxide that, in addition to reducing the parasite load in mice, also increased the quantity of survivals to $100 \%$.

Another important step is to establish the understanding that the pathology is the knowledge of immunological and metabolic mechanisms of the carrier. Currently, there are no scientific explanations to the conversion of the chronic undetermined form (asymptomatic) to the chronic symptomatic form (cardiac, digestive or mixed). The Medicine College of Botucatu (FMB/ Unesp) has several groups of researches in different areas of knowledge for the study of CD. The authors of this study are part of a study group in the Tropical Diseases Laboratory of this institution. Immunologic, molecular and metabolic researches were made.

Currently, one of these groups is trying to relate the lipid profile and nutritional of the carriers of CD with pro inflammatory cytokines and nitric oxide, already possessing preliminary results that will be published soon. 
Thus it can be concluded that Brazil is ahead in controlling this endemic disease in the country both as regards the measures taken by the public authorities as basic research and development of new treatments, but the challenges continue.

\section{Acknowledgements}

We would like thank Nelson Montilhiade FariaNeto for language revision.

\section{REFERENCES}

Araújo, A., Jansen, A. A., Reinhard, K., \& Ferreira, L. F. (2009). Paleoparasitology of Chagas disease-A review. Memórias do Instituto Osvaldo Cruz, 104, 9-16.

http://dx.doi.org/10.1590/S0074-02762009000900004

Aufderhreide, A. C., Salo, W., Madden, M., Streiz, J., Buikstra, J., Guhl, F. et al. (2004). A 9000-year record of Chagas' disease. PNAS, 101, 2034-2039.

Bern, C., \& Montgomery, S. P. (2009). An estimate of the burden of Chagas diseases inthe United States. Clinical Infectious Diseases, 49, 52-54. http://dx.doi.org/10.1086/605091

Brito, C. R. N., Sampaio, G. H. F., Câmara, A. C. J., Nunes, D. F., Azevedo, P. R. M., Chiari, E. et al. (2012). Seroepidemiology of Trypanosoma cruzi infection in the semiarid rural zone of the State of Rio Grande do Norte, Brazil. Revista da Sociedade de Medicina Tropica, 5, 346-352. http://dx.doi.org/10.1590/S0037-86822012000300013

Carvalho, M. E., Silva, R. A., Wanderley, D. M. V., \& Barata, J. M. S. (2011). Programa de controle da doença de Chagas no Estado de São Paulo: Aspectos soroepidemiológicos em microrregiões geográficas homogêneas. Revista da Sociedade Brasileira de Medicina Tropical, 44, 95-106.

Chagas, C. (2008). A new diseaseentity in man: A report onetiologic and clinical observations. International Journal of Epidemiology, 37, 694-695.

Flores-Chavez, M. D., Merino, F. J., García-Bujalance, S., MartinRabadán, P., Merino, P., García-Bermejo, I. et al. (2011). Surveillance of Chagas disease in pregnant women in Madrid, Spain, from 2008 to 2010. Eurosurveillance, 16, 1-7.

Combs, T. P., Nagajyothi, Mukherjee, S., Almeida, C. J. G., Jelicks, L. A., Schubert, W. et al. (2005). The adipocyte as an important target cell for Trypanosoma cruzi infection. The Journal of Biological Chemistry, 280, 24085-24094.

http://dx.doi.org/10.1074/jbc.M412802200

Coura, J. R., \& Borges-Pereira, J. (2011). Chronic phase of Chagas disease: Why should it be treated? A comprehensivereview. Memórias do Instituto Oswaldo Cruz, 106, 641-645.

Coura, J. R. (2007). Origem, determinantes e morbidade da doença de chagas. Revista de la Facultad de Ciencias de laSalud, 11, 62-66.

Coura, J. R. (1997). Síntese histórica e evolução dos conhecimentos sobre a doença de chagas. In Clínica e terapêutica da doença de Chagas: Uma abordagem prática para o clínico geral (486 p). Editora FIOCRUZ, Rio de Janeiro. http://books.scielo.org

Dias, J. C. P., Neto, V. A., \& Luna, E. J. A. (2011). Mecanismos alternativos de transmissão do Trypanosoma cruzi no Brasil e sugestões para sua prevenção. Revista da Sociedade Brasileira de Medicina Tropical, 44, 375-379.

http://dx.doi.org/10.1590/S0037-86822011005000032

Dias, J. C. P. (2006). Doença de Chagas e transfusão de sangue no Brasil: Vigilância e desafios. Revista Brasileira de Hematologia, 28, 83-84.

Fernandes, A., Iñiguez, A. M., Lima, V. S., Souza, S. M. F. M., Ferreira, L. F., Vicente, A. C. P., \& Jansen, A. M. (2008). Pre-Columbian Chagas disease in Brazil: Trypanosoma cruzi I in the archaeological remains of a human in Peruaçu Valley, Minas Gerais, Brazil. Memórias do Instituto Oswaldo Cruz, 103, 514-516. http://dx.doi.org/10.1590/S0074-02762008000500021
Ferreira, A. V. M., Segatto, M., Menezes, Z., Macedo, A. M., Gelape, C., Andrade, L. O. et al. (2011). Evidence for Trypanosoma cruzi in adipose tissue in human chronic Chagas disease. Microbes and Infection, 13, 1002-1005.

http://dx.doi.org/10.1016/j.micinf.2011.06.002

Fitarelli, D. B., \& Horn, J. F. (2009). Descarte de bolsas de sangue devido à reatividade para doença de Chagas em um laboratório de triagem sorológica de doadores em Porto Alegre-RS. Revista Brasileira de Hematologia, 31, 310-314. http://dx.doi.org/10.1590/S1516-84842009005000066

Flores-Chaves, M. D., Merino, F. J., Bujalance, S. G., Martin-Rabadán, P., Merino, P., Gárcia-Bermejo I. et al. (2011). Surveillance of Chagas disease in pregnant women in Madrid, Spain, from 2008 to 2010. Eurosurveillance, 16, 1-6.

http://www.eurosurveillance.org

Geraix, J., Ardisson, L. P., Marcondes-Machado, J., \& Pereira, P. C. M. (2007). Clinical and nutritional profile of individuals with Chagas disease. The Brazilian Journal of Infectious Diseases, 11, 411-414. http://dx.doi.org/10.1590/S1413-86702007000400008

Goldbaum, M., \& Barreto, M. L. (2008). Commentary: The contribution and example of Carlos Chagas. International Journal of Epidemiology, 37, 697-698.

Kropf, S. P. (2013). Carlos Chagas: Infância, primeiros estudos e formação médica.

http://www.fiocruz.br/chagas/cgi/cgilua.exe/sys/start.htm?sid=1

Lescure, F. X., Loup, G. L., Freilij, H., Develoux, M., Paris, L., Brutus, L. et al. (2010). Chagas disease: Changes in knowledge and management. Lancet Infection Disease, 10, 556-570. http://dx.doi.org/10.1016/S1473-3099(10)70098-0

Lucheis, S. B., Silva, A. V., Araújo Jr., J. P., Langoni, H., Meira, D. A., \& Marcondes-Machado, J. (2005). Trypanosomatids in dogs belonging to individuals with chronic Chagas' disease living in Botucatu town and surrounding region, São Paulo State, Brazil. The Journal of Venomous Animals and Toxins including Tropical Diseases, 11, $492-$ 509. http://dx.doi.org/10.1590/S1678-91992005000400009

Moraes-Souza, H., \& Ferreira-Silva, M. M. (2011). O controle da transmissão transfusional. Revista da Sociedade Brasileira de Medicina Tropical, 44, 64-67.

Moncayo, A., \& Silveira, A. C. (2009). Current epidemiological trends for Chagas disease in Latin America and future challenges in epidemiology, surveillance and health policy. Memórias do Instituto Oswaldo Cruz, 104, 17-30.

Nagajyothi, F., Machado, F. S., Burleigh, B. A., Jelicks, L. A., Scherer, P. E., Mukherjee, S. et al. (2012). Mechanisms of Trypanosoma cruzi persistence in Chagas disease. Cellular Microbiology, 14, 634-643. http://dx.doi.org/10.1111/j.1462-5822.2012.01764.x

Nagajyothi, F., Desruisseaux, M. S., Weiss, L. M., Chua, S., Albanese, C., Machado, F. S. et al. (2009). Chagas disease, adipose tissue and the metabolic syndrome. Memórias do Instituto Oswaldo Cruz, 104, 2019-2225.

Navarro, E. C., Abreu, M. M., Tavares, F. C., Corrente, J. E., Arruda, C. M., \& Pereira, P. C. M. (2013b). Indeterminate form of Chagas' disease and metabolic syndrome: A dangerous combination. American Journal of Medicine and Medical Science, 3, 68-73.

Navarro, E. C., Pereira, P. C. M., Goto, R. L., Ricaboni, I., Henriques, R. M. S., Neves, S. L., Xanini, J. M., \& Dorini, A. A. (2013a). Seroprevalence of chagasic infection in young individuals in a blood center in the State of São Paulo, Brazil. Revista do Instituto de Medicina Tropical de São Paulo, 55, 245-250. http://dx.doi.org/10.1590/S0036-46652013000400005

Navarro, M., Navaza, B., Guionnet, A., \& López-Vélez, R. (2012). Chagas disease in Spain: Need for further public health measures. PLOS Neglected Tropical Diseases, 12, 1-4. http://dx.doi.org/10.1371/journal.pntd.0001962

Nóbrega, A. A., Garcia, M. H., Tatto, E., Obara, M. T., Costa, E., Sobel, J. et al. (2009). Oral transmission of Chagas disease by consumption of Açaí palm fruit, Brazil. Emerging Infectious Diseases, 15, 653655. http://dx.doi.org/10.3201/eid1504.081450

Ostermayer, A. L., Passos, A. D. C., Silveira, A. C., Ferreira, A. W., Macedo, V., \& Prata, A. R. (2011). The national survey of seroprevalence for evaluation of the control of Chagas disease in Brazil 


\section{E. C. NAVARRO, P. C. M. PEREIRA}

(2001-2008). Revista da Sociedade Brasileira de Medicina Tropical, 44, 108-121.

Pan American Health Organization (2012). Notas descriptivasEnfermedad de Chagas.

http://new.paho.org/hq/index.php?option=com_content\&view=articl e\&id=5856\&Itemid $=4196$

Petherick, A. (2010). Country by country. Nature, 465, S10-S11. http://dx.doi.org/10.1038/nature09223

Picka, M. C. M., Meira, D. A., Carvalho, T. B., Peresi, E., \& Marcondes-Machado, J. (2007). Definition of a diagnostic routine in individuals with inconclusive serology for Chagas disease. The Brazilian Journal of Infectious Diseases, 11, 226-233. http://dx.doi.org/10.1590/S1413-86702007000200012

Rassi Jr., A., Rassi, A., \& Marin-Neto, J. A. (2010). Chagas disease. Lancet, 375, 1388-1402.

http://dx.doi.org/10.1016/S0140-6736(10)60061-X

Rey, L. (2011). Parasitologia (4 ed.). Rio de Janeiro: Guanabara Koogan.

Rissio, A. M., Riarte, A. R., Garcia, M. M., Esteva, M. I., Quaglino, M., \& Ruiz, A. M. (2010). Congenital Trypanosoma cruzi infection. Efficacy of its monitoring in na urban reference health Center in a nonendemic area of Argentina. The American Journal of Tropical Medicine and Hygiene, 82, 838-845.

http://dx.doi.org/10.4269/ajtmh.2010.08-0383

Romero, M., Postigo, J., Schneider, D., Chippaux, J. P., Santalla, J. A., \& Brutus, L. (2011). Door-to-door screening as a strategy for the detection of congenital chagas disease in rural Bolívia. Tropical Me- dicine and International Health, 16, 562-569.

http://dx.doi.org/10.1111/j.1365-3156.2011.02746.x

Schapachnik, E., Riera, A. R. P., Dubner, S., Filho, C. F., Uchida, A. H., \& Ferreira, C. (2009). Dr. Carlos justiniano ribeiro das chagas (18791934): A giant of the Third World. Cardiology Journal, 16, 592-593.

Sathler-Avelar, R., Vitelli-Avelar, D., Teixeira-Carvalho, A., MartinsFilho, O. A. (2009). Innate immunity and regulatory T-cells in human chagas disease: What must be understood? Memórias do Instituto Oswaldo Cruz, 104, 246-251. http://dx.doi.org/10.1590/S0074-02762009000900031

Silveira, A. C., \& Junior, F. P. (2011). A inserção institucional do controle da doença de chagas. Revista da Sociedade Brasileira de Medicina Tropical, 44, 19-24. http://dx.doi.org/10.1590/S0037-86822011000800004

Soares, L. M. B. (2009). Eliminação da transmissão e morbidade da infecção chagásica crônica em pacientes autóctones da microrregião do rio negro, Estado do Amazonas (1997-2008). Dissertação. Rio de Janeiro: Instituto Osvaldo Cruz.

Tanowitz, H. B., Julicks, L. A., Machado, F. S., Esper, L., Qi, X., Deruisseaux, M. S., et al. (2011). Adipose tissue, diabetes and chagas disease. Advances in Parasitology, 76, 235-250. http://dx.doi.org/10.1016/B978-0-12-385895-5.00010-4

Zingales, B. (2011). Trypanosoma cruzi: One parasite, two parasites or several parasites of chagas disease? Revista da Biologia,6b, 44-48. http://dx.doi.org/10.7594/revbio.6b.09 